ORIGINAL ARTICLE

\title{
Systematic review of transpyloric versus gastric tube feeding for preterm infants
}

\author{
W McGuire, P McEwan
}

Arch Dis Child Fetal Neonatal Ed 2004;89:F245-F248. doi: 10.1136/adc.2002.022459

See end of article for authors' affiliations .....................

Correspondence to: Dr McGuire, Tayside Institute of Child Health Ninewells Hospital and Medical School, Dundee DDI 9SY, Scotland, UK; w.mcguire@dundee.ac.uk

Accepted 2 July 2003

\begin{abstract}
Aim: To determine if enteral tube feeding by the transpyloric versus the gastric route improves feeding tolerance, and growth and development, without increasing adverse events, in preterm infants.

Methods: Systematic review of randomised controlled trials. A search was made of the Cochrane Controlled Trials Register (CCTR; 2003, issue 1), Medline (1966 to April 2003), and Embase (1980 to April 2003), and references in previous reviews. The data were extracted, analysed, and synthesised using the standard methods of the Cochrane Neonatal Collaborative Review Group.

Results: Data were found from eight trials. No evidence of an effect on growth or development was found, but transpyloric feeding was associated with a greater incidence of gastrointestinal disturbance: relative risk (RR) 1.45, 95\% confidence interval (CI) 1.05 to 2.09. Transpyloric feeding was also associated with increased mortality: RR $2.46,95 \% \mathrm{Cl} 1.36$ to 4.46 . However, the trial that contributed most to this finding may have been affected by allocation bias. No significant differences were detected in the incidence of other adverse events, including necrotising enterocolitis, intestinal perforation, and aspiration pneumonia. Conclusions: No evidence of benefit was found, but evidence of harm was found. Feeding by the transpyloric route cannot be recommended for preterm infants.
\end{abstract}

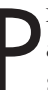
reterm infants often have poor coordination of sucking and swallowing, and this can delay the establishment of safe oral feeding. Enteral feeds may be delivered through a catheter passed through the nose or the mouth into the stomach or upper small bowel.

In preterm infants, the gastro-oesophageal valve is more lax, and gastric peristalsis and emptying is less effective than in term infants. ${ }^{1}$ Placement of the enteral feeding tube in the duodenum or jejunum (transpyloric) ensures delivery of enteral feeds to the main sites of nutrient absorption, and has the theoretical advantage of decreasing the potential for oesophageal reflux and aspiration of milk into the lungs. However, feeding by the transpyloric route has potential problems. The gastric phase of the digestion is bypassed, and secretion of intestinal hormones and growth factors may be impaired. ${ }^{2}$ There is also a risk that potentially pathogenic organisms that would have been removed in the acidic environment of the stomach may be delivered to the small bowel. ${ }^{3}$ These factors may contribute to an increased risk of gastrointestinal disturbance or necrotising enterocolitis in infants fed by the transpyloric route, as suggested by casecontrol data. ${ }^{4}$ In addition, transpyloric feeding tubes are difficult to position, and, after placement, the transpyloric tube may still migrate back to the stomach. Serious adverse events, including cases of intestinal perforation and pyloric stenosis, have also been reported. ${ }^{56}$

We have undertaken a systematic review to determine if feeding by the transpyloric rather than the gastric route improves feeding tolerance, and growth and development, without increasing adverse consequences (death, gastrointestinal disturbance, necrotising enterocolitis, aspiration pneumonia, chronic lung disease, pyloric stenosis) in preterm infants who require tube feeding.

\section{METHODS}

We used the standard search strategy of the Cochrane Neonatal Collaborative Review Group (http://cochrane. mcmaster.ca/neonatal/). This included searches of the Cochrane Controlled Trials Register (CCTR; 2003, issue 1),
Medline (1966 to April 2003), and Embase (1980 to April 2003). The search strategy included the following text words and MeSH subject headings: "Infant-Newborn"/all subheadings, infan*, neonat*, newborn, prematur*, preterm, explode "Infant-Nutrition"/all subheadings, explode "Feeding-Methods"/all subheadings, explode "Intubation, Gastrointestinal"/all subheadings, gastric, transpyloric, nasoduodenal, nasojejunal. The searches were limited to "clinical trial". We did not apply any language restriction.

We examined references in the studies identified as potentially relevant, and in previous reviews and textbooks of neonatal medicine. The first reviewer screened the title and abstract of studies identified by the above search strategy. Both reviewers rescreened the full text of the report of each potentially relevant study. Only studies that met all of the specified inclusion criteria (table 1) were included. The reviewers resolved any disagreement by discussion.

We evaluated the quality of the trials in terms of allocation concealment, blinding of parents or carers and assessors to intervention, and completeness of assessment in all randomised individuals. We examined heterogeneity between trial results using a $\chi^{2}$ test for dichotomous outcomes and analysis of variance for continuous outcomes. We have expressed the effects as relative risk (RR) and $95 \%$ confidence interval (CI) and risk difference (RD) and $95 \%$ CI for categorical data, and weighted mean difference (WMD) and 95\% CI for continuous data. We used a fixed effect model for meta-analysis. We did not specify any subgroup analyses.

\section{RESULTS}

\section{Search findings}

Overall, 21 studies that appeared to be relevant were identified in the first round of screening. We then excluded 13 reports as these were unlikely to be randomised or quasirandomised trials. ${ }^{7-19}$

We included eight studies, enrolling a total of 340 infants. ${ }^{20-27}$ One of the studies ${ }^{24}$ was reported previously in 
Table 1 Specified criteria for inclusion of studies

$\begin{array}{ll}\text { Studies: } & \text { Randomised or quasi-randomised (for example, alternate allocation, or allocation by date of } \\ \text { birth or day of year) controlled trials. } & \text { Preterm infants (less than } 37 \text { weeks gestation) who needed enteral tube feeding, cared for in a } \\ \text { Participants: } & \text { hospital setting. } \\ \text { Interventions: } & \text { Transploric versus gastric tube feeding with catheters passed through the nose or mouth. Trials } \\ \text { of gastrostomy, duodenostomy, or jejunostomy feeding were not included. } \\ \text { Outcomes: } \\ \text { 1. Growth, development, and feeding } \\ \text { a. Short term (before discharge from hospital) growth parameters } \\ \text { b. Longer term (after discharge from hospital) growth parameters } \\ \text { c. Neurodevelopmental outcomes during infancy and beyond using validated } \\ \text { d. Time from birth to establish full oral feeds } \\ \text { e. Time from birth to establish full enteral tube feeds } \\ \text { Adverse events } \\ \text { a. Death before discharge from hospital } \\ \text { b. Gastrointestinal disturbance such as diarrhoea or feeding intolerance that results in } \\ \text { c. Nessation of enteral feeding } \\ \text { d. Aspiratising enterocolitis } \\ \text { e. } \text { respiratory tract compromia/pneumonitis: clinical and/or radiological evidence of lower } \\ \text { e. Intestinal perforation }\end{array}$

abstract form only. ${ }^{28}$ Table 2 shows the main characteristics, and table 3 shows the quality assessment of these trials. In most of the studies, allocation was not concealed. This may be of particular importance with regard to the largest of the included studies. ${ }^{21}$ In this study, the infants who were allocated to transpyloric feeding were of significantly lower gestational age (mean 27.7 weeks $v 28.5$ weeks in the gastric feeding group), and had significantly lower Apgar scores at one minute (mean $3.6 v 6.2$ ) and five minutes (mean $6.3 v$ 8.3). It is possible that, because of allocation bias, some of the less mature and sicker infants may have been allocated preferentially to transpyloric feeding.

\section{Growth, development, and feeding}

Five studies reported changes in weight, length, and head circumference..$^{20-24}$ There were no significant differences in the growth variables in any of the trials. We undertook meta-analyses where sufficient data (mean and standard deviation) were available, and these did not show any significant differences. One study reported longer term (after hospital discharge) growth. ${ }^{27}$ At the expected date of delivery, weight and head circumference were significantly less in the transpyloric than the gastric group. There were no significant differences at three months and six months after the expected date of delivery. However, because of loss to follow up, mainly in the transpyloric feeding group, these data should be interpreted cautiously.

None of the included studies reported neurodevelopmental outcomes.

The two studies that reported the time taken to establish full enteral tube feeding did not find any significant differences. ${ }^{22} 23$ The time taken to establish full oral feeding was not reported by any of the included studies.

\section{Adverse events}

Adverse events were often reported as withdrawal criteria, rather than as defined outcome measures. In most of the reports, we determined the incidence of adverse events for the complete or near complete cohort.

Death before discharge from hospital

Six trials reported this outcome. ${ }^{20-2225-27}$ One trial found that transpyloric feeding was associated with a significantly higher mortality, but this finding may have been affected

Table 2 Characteristics of included studies: participants, intervention, and outcome

\begin{tabular}{|c|c|c|c|c|}
\hline Trial (year) & Participants & Interventions (feeding route) & Duration & Outcomes \\
\hline Drew $^{20}(1979)$ & $\begin{array}{l}\text { Appropriate for gestational age } \\
\text { infants, birth weight }<1500 \mathrm{~g} \text {, not } \\
\text { needing assisted ventilation }\end{array}$ & $\begin{array}{l}\text { Nasojejunal: } n=32 \\
\text { Nasogastric: } n=34\end{array}$ & $\begin{array}{l}\text { Until achieving an enteral } \\
\text { intake of } 200 \mathrm{ml} / \mathrm{kg} / \text { day }\end{array}$ & $\begin{array}{l}\text { Growth } \\
\text { Adverse events }\end{array}$ \\
\hline Laing $^{21}$ (1986) & $\begin{array}{l}\text { Appropriate for gestational age } \\
\text { infants, birth weight }<1500 \mathrm{~g}\end{array}$ & $\begin{array}{l}\text { Continuous nasoduodenal: } n=45 \\
\text { Intermittent nasogastric: } n=35\end{array}$ & Seven weeks & $\begin{array}{l}\text { Growth } \\
\text { Adverse events }\end{array}$ \\
\hline Macdonald $^{22}$ (1992) & $\begin{array}{l}\text { Formula fed infants, birth weight } \\
<1400 \mathrm{~g}\end{array}$ & $\begin{array}{l}\text { Continuous nasoduodenal: } n=15 \\
\text { Bolus nasogastric: } n=15 \\
\text { Continuous nasogastric: } n=13\end{array}$ & Until weight $\geqslant 1600 \mathrm{~g}$ & $\begin{array}{l}\text { Growth } \\
\text { Time to full enteral feeding } \\
\text { Adverse events }\end{array}$ \\
\hline Pereira $^{23}(1981)$ & $\begin{array}{l}\text { Infants, birth weight }<1700 \mathrm{~g} \text { or } \\
\text { gestation }<33 \text { weeks }\end{array}$ & $\begin{array}{l}\text { Continuous nasojejunal: } n=26 \\
\text { Intermittent nasogastric: } n=27\end{array}$ & Until breast feeding & $\begin{array}{l}\text { Growth } \\
\text { Adverse events }\end{array}$ \\
\hline $\operatorname{Roy}^{24}(1975)$ & $\begin{array}{l}\text { Appropriate for gestational age } \\
\text { infants, birth weight }<1500 \mathrm{~g} \text {, not } \\
\text { needing assisted ventilation }\end{array}$ & $\begin{array}{l}\text { Continuous nasojejunal: } n=12 \\
\text { Intermittent nasogastric: } n=9\end{array}$ & Seven days & Growth \\
\hline Van Caillie ${ }^{25}$ (1975) & $\begin{array}{l}\text { Preterm infants, birth weight } \\
<1300 \mathrm{~g}\end{array}$ & $\begin{array}{l}\text { Continuous nasoduodenal: } n=6 \\
\text { Continuous nasogastric } n=5\end{array}$ & 40 days & $\begin{array}{l}\text { Growth } \\
\text { Adverse events }\end{array}$ \\
\hline Wells $^{26}(1975)$ & $\begin{array}{l}\text { Preterm infants, birth weight } \\
<1500 \mathrm{~g}\end{array}$ & $\begin{array}{l}\text { Continuous nasojejunal: } n=1 \\
\text { Intermittent nasogastric: } n=11\end{array}$ & 21 days & $\begin{array}{l}\text { Growth } \\
\text { Adverse events }\end{array}$ \\
\hline Whitfield ${ }^{27}$ (1982) & $\begin{array}{l}\text { Appropriate for gestational age } \\
\text { infants, birth weight } 1000-1500 \mathrm{~g}\end{array}$ & $\begin{array}{l}\text { Continuous nasojejunal: } n=28 \\
\text { Intermittent nasogastric: } n=16\end{array}$ & Until weight $\geqslant 1500 \mathrm{~g}$ & $\begin{array}{l}\text { Growth (until six months old) } \\
\text { Adverse events }\end{array}$ \\
\hline
\end{tabular}


Table 3 Methodological quality of included studies

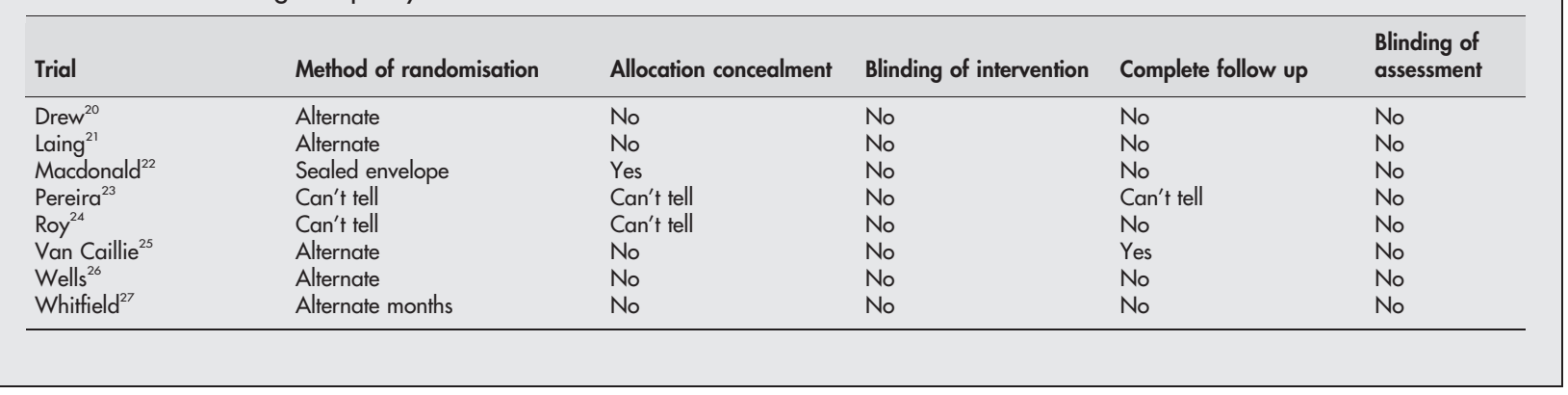

by allocation bias. $^{21}$ In a meta-analysis, there was a significantly higher rate of death in the infants who were fed by the transpyloric route: RR: 2.5 (95\% CI 1.4 to 4.5 ); RD: 0.16 (95\% CI 0.07 to 0.26 ). When the study with possible allocation bias was excluded, the increase in mortality in the transpyloric group was not quite significant: RR: 2.2 (95\% CI 0.9 to 5.4 ); RD: 0.1 (95\% CI 0.00 to 0.2 ).

\section{Gastrointestinal disturbance}

None of the seven trials that reported this outcome found any significant difference. ${ }^{20-23}$ 25-27 Meta-analysis showed a significantly increased risk of gastrointestinal disturbance in the infants fed by the transpyloric route: RR: 1.5 (95\% CI 1.1 to 2.1); RD: 0.1 (95\% CI 0.02 to 0.17 ). A significant difference remained when the study with possible allocation bias was removed: RR: 1.4 (95\% CI 1.02 to 2.0 ); RD: 0.1 (95\% CI 0.01 to 0.21$)$.

\section{Necrotising enterocolitis}

None of the seven trials that reported this outcome, ${ }^{20-23}{ }^{25-27}$ nor a meta-analysis of the studies, found any significant difference: RR: 0.6 (95\% CI 0.3 to 1.5 ); RD: -0.03 (95\% CI -0.09 to 0.03 ).

\section{Aspiration pneumonia}

None of the four trials that reported this outcome, ${ }^{20} 222325$ nor a meta-analysis, found any significant difference: RR: 1.4 (95\% CI 0.4 to 4.2 ); RD: 0.02 (95\% CI -0.06 to 0.1 ).

\section{Intestinal perforation}

None of the four trials that reported this outcome, ${ }^{23-25} 27$ nor a meta-analysis, found any significant difference: RR: 2.3 (95\% CI 0.1 to 50.1 ); RD: 0.01 ( $95 \%$ CI -0.05 to 0.08 ).

Pyloric stenosis and chronic lung disease

These outcomes were not reported in any of the trials.

\section{DISCUSSION}

We have found evidence that transpyloric feeding is associated with increased mortality in preterm infants. However, many of the studies included in the review had a variety of methodological weaknesses, and this finding should be interpreted with caution. In particular, the outcomes for the largest included trial may have been affected by preferential allocation of some of the less mature or sicker infants to transpyloric feeding. When this study was excluded from the meta-analysis, the increase in mortality was not quite significant.

We also found the incidence of gastrointestinal disturbance to be significantly higher in infants fed by the transpyloric route. "Gastrointestinal disturbance" included a variety of clinically important problems such as abdominal distension, gastric bleeding, and bilious vomiting, which resulted in cessation of enteral feeding. Most of the trials recruited infants of birth weight less than $1500 \mathrm{~g}$, but infants with intrauterine growth restriction were excluded in at least six of the trials. As this subpopulation may be at increased risk of adverse events related to enteral feeding, ${ }^{29}$ this factor limits the applicability of the findings of this review. In addition, although it may have been pragmatic to compare continuous transpyloric feeding with intermittent or bolus gastric feeding, as was the case in seven of the included studies, it should be noted that this covariable may also have affected the outcomes. The Cochrane review that compared continuous nasogastric tube feeding with intermittent bolus feeding for very low birthweight infants concluded that the clinical benefits and risks could not be reliably discerned from the available data. ${ }^{30}$

We did not find any evidence that feeding by the transpyloric route compared with the gastric route affects the rate of growth. However, in many of the trials, the growth data from infants who developed complications during the study period, or in whom enteral tube placement was unsuccessful, were not reported. In the largest included trial, only 41 of the 80 infants who entered the study were included in the growth data analysis. ${ }^{21}$ In another trial, there were outcome data for only 44 of the 66 infants allocated to a feeding route. ${ }^{20}$ It may be that repeated failed attempts to position the transpyloric tube introduced a delay in starting or establishing nutritional input. As it is plausible that such a delay may affect growth, the findings may have been different in a true intention to treat analysis.

A clinically plausible putative benefit of transpyloric tube feeding is a reduced risk of aspiration pneumonia. This review did not find any evidence that this is the case. The narrow $95 \%$ confidence intervals, estimating the effect to lie between a $5 \%$ reduction in risk and a $10 \%$ increase in risk, suggest that a modest effect on aspiration pneumonia has not been missed.

\section{Conclusion}

The limited available evidence suggests that the transpyloric route should not be used routinely for preterm infants who require enteral tube feeding. The lack of evidence of any benefit, and the finding of an increased risk of gastrointestinal disturbance and possibly of death, suggest that a randomised controlled trial of transpyloric versus gastric tube feeding in preterm infants is not a priority.

\section{Authors' affiliations \\ W McGuire, P McEwan, Tayside Institute of Child Health, Ninewells Hospital and Medical School, Dundee DD1 9SY, Scotland, UK}

\section{REFERENCES}

1 Berseth CL. Gestational evolution of small intestine motility in preterm and term infants. J Pediatr 1989;115:646-51. 
2 Milner RD, Minoli I, Moro G, et al Growth and metabolic and hormonal profiles during transpyloric and nasogastric feeding in preterm infants. Acto Paediatr Scand 1981;70:9-13.

3 Dellagrammaticas HD, Duerden BI, Milner RD. Upper intestinal bacterial flora during transpyloric feeding. Arch Dis Child 1983;58:115-19.

4 Vinocur $\mathbf{P}$, Stine MJ. Risk factors for late onset necrotising enterocolitis. Indiana Med 1990;83:478-80.

5 Raine PA, Goel KM, Young DG, et al. Pyloric stenosis and transpyloric feeding. Lancet 1982:2:821-2.

6 McAlister WH, Siegel MJ, Shackelford GD, et al. Intestinal perforations by tube feedings in small infants: clinical and experimental studies. AJR Am J Roentgenol 1985;145:687-91.

7 Agarwal RK, Jindal N. Nasojejunal and nasoduodenal tube feeding. Indian Pediatr 1980;17:472-5.

8 Avery GB. Nasoduodenal versus nasogastric feeding. Pediatrics 1977;60:550-1.

9 Boros SJ, Reynolds JW. Duodenal perforation: a complication of neonatal nasojejunal feeding. J Pediatr 1974;85:107-8.

10 Celestin LR. Nasojejunal feeding. Lancet 1978;2:992-3.

11 Cheek JA Jr, Staub GF. Nasojejunal alimentation for premature and full-term newborn infants. J Pediatr 1973;82:955-62.

12 Chen JW, Wong PW. Intestinal complications of nasojejunal feeding in low birth weight infants. J Pediatr 1974:85:109-10.

13 Loo SWH, Gross I, Warshaw JB. Improved methods of nasojejunal feeding in low birth weight infants. J Pediatr 1974;85:104-6.

14 Minoli I, Moro G. Transpyloric and intermittent gavage feeding. Pediatrics 1982;69:133.

15 Price E, Gyotoku S. Using the nasojejunal feeding technique in a neonatal intensive care unit. MCN Am J Matern Child Nurs 1978;3:361-5.

16 Pyati S, Ramamurthy R, Pildes R. Continuous drip nasogastric feedings: a controlled study [abstract]. Pediatr Res 1976;10:359.

17 Uauy R, Loo S, Gross I, et al. Nasojejunal feeding in the small premature infant: a controlled trial [abstract]. Pediatr Res 1975;9:309.
18 Valman HB Brown RJ Intragastric versus nasoiejunal feeding of low-birthweigh infants. J Pediatr 1973;83:1095-6.

19 Wolfsdorf J, Makarawa S, Fernandes C, et al. Transpyloric feeding in small preterm infants. Arch Dis Child 1975;50:723-6.

20 Drew JH, Johnston R, Finocchiaro C, et al. A comparison of nasojejunal with nasogastric feedings in low-birth-weight infants. Aust Paediatr $J$ 1979;15:98-100.

21 Laing IA, Lang MA, Callaghan O, et al. Nasogastric compared with nasoduodenal feeding in low birth weight infants. Arch Dis Child 1986;61:138-41

22 Macdonald PD, Skeoch $\mathrm{CH}$, Carse $\mathrm{H}$, et al. Randomised trial of continuous nasogastric, bolus nasogastric, and transpyloric feeding in infants of birth weight under $1400 \mathrm{~g}$. Arch Dis Child 1992;67:429-31.

23 Pereira GR, Lemons JA. Controlled study of transpyloric and intermittent gavage feeding in the small preterm infant. Pediatrics 1981;67:68-72.

24 Roy RN, Pollnitz RP, Hamilton JR, et al. Impaired assimilation of nasojejunal feeds in healthy low birth weight infants. J Pediatr 1977;90:431-4.

25 Van Caillie M, Powell GK. Nasoduodenal versus nasogastric feeding in the very low birth weight infant. Pediatrics 1975;56:1065-72.

26 Wells DH, Zachman RD. Nasojejunal feedings in low birth weight infants. J Pediatr 1975;87:267-79.

27 Whiffield MF. Poor weight gain of the low birthweight infant fed nasojejunally. Arch Dis Child 1982;57:597-601.

28 Roy N, Pollnitz R, Hamilton R, et al. Impaired assimilation of nasojejunal feeds in very low birth weight infants. Pediatr Res 1976;10:359.

29 McDonnell M, Serra Serra V, Gaffney G, et al. Neonatal outcome after pregnancy complicated by abnormal velocity waveforms in the umbilical artery. Arch Dis Child 1994;70:F84-9.

30 Premii S, Chessell L. Continuous nasogastric milk feeding versus intermittent bolus milk feeding for premature infants less than 1500 grams (Cochrane Review). Cochrane Library, Issue 3. Oxford: Update Software, 2002. 